\title{
SEXUAL DIVERSITY AND GENDER IDENTITY IN SRI LANKAN PERSPECTIVE WITH SPECIAL REFERENCE TO RIGHTS AND POSITION OF SEXUAL MINORITIES IN CRIMINAL JUSTICE SYSTEM OF SRI LANKA
}

\author{
A. H. Wijayath* \\ Independent Researcher, Sri Lanka
}

\begin{abstract}
All human beings have acquired a set of rights since their birth and these rights are called "Human Rights". These set of rights cannot be derogated due to the sexual orientation. The Constitution of Sri Lanka states that all citizens are equal before the law and every citizen have the same opportunity without considering their sexual orientation. The Penal Code of Sri Lanka prescribes that, the sex between men and sex between women as offences. This research mainly focused on sexual minorities and their position in Sri Lankan Criminal Justice arena. Through this study, the rights of sexual minorities and penal laws relating to sexual behaviours will be discussed in a critical manner. The purpose of this research is gathering qualitative information in relation to rights of sexual minorities and it further analyzes the penal laws regarding homosexual behaviours in Sri Lankan Criminal Justice System. Generally, this work is internet based research therefore scholarly work on the issue will be reviewed. This qualitative information will help in the formulation of recommendations to build up a better surrounding for sexual minorities and ameliorate their position in Sri Lankan society.
\end{abstract}

Keywords: Sexual minorities, Human Rights, Penal Code of Sri Lanka, Criminal Justice System

\section{Introduction}

The term "Sexual Diversity" is often used to describe the sexual characteristics, sexual orientation and gender identity of human society. Sexual diversity means, which every human being has own understanding of what sex means to them. Gender identity refers to "one's self-identification as male, female or an alternative gender." The sexual diversity and gender identity have a broad spectrum of expressions, identities, behaviours, feelings of attraction. The sexual characteristics of all human beings are not heterosexual, some are gay, lesbian, bisexual, queer or questioning. Sexual diversity and gender identity of human beings are a comprehensive concept associates with biological factors, social factors and behavioural factors. The Umbrella term LGBT (Lesbian, Gay, Bisexual and Transgender)/ LGBTIQ (Lesbian, Gay, Bisexual, Transgender/Trans sex, Intersex and Queer/Questioning) is used to describe the sexual minor community. LGBT community is described as "sexual minority" because they differ from the major heterosexual oriented society. The sexual minorities have different necessities and their expectations are different from large heteronormative value oriented context.

With regard to South Asian context, the third gender has a traditional recognition from the ancient history. They acted a significant role in cultural, religious, ritual functions, dance and Theatre. Hijra is an Indian crossdressing male community exists from ancient history. India, Nepal and Bangladesh have taken steps to recognize the third gender even though, Sri Lanka does not accept the concept of the third gender due to the social, cultural and religious influences. A majority of general public represents the hetero-patriarchal dominant 
society and the same-sex relationship is commentated as a forbidden and anti-social activity. Further, the LGBT activists are labelled as perverts and their activities are being named as anti-moral practices.

At present, many countries have taken steps to decriminalize homosexual activities and legalize same-sex marriages. However, 75 countries including Sri Lanka criminalize homosexuality and 6 countries and some parts of Somalia and Nigeria impose capital punishment for the offence of homosexuality.

Like many colonial territories, the Sri Lankan judicial system also inherited by British rules of the Victorian era. The procedural law such as the Penal Code of Sri Lanka was formulated by British. Through the root codification of Penal Code, the sex between men are criminalized even though, the existence of sex among women was not even admitted by it. Through 1995 amendments to the Penal Code, the lesbianism also identified as a criminal offence in Sri Lanka.

A considerable percentage of sexual minorities dwell in Sri Lanka whereas a lesser population is exposed to the public due to detestation is arisen from the society upon them. According to the fundamental rights of the Constitution of Sri Lanka, any person shall not be discriminated due to their sex, even though the sexual minorities are flagrantly discriminated by the general public. Furthermore, they are ceaselessly confronted with denial of rights, social phobia, and psychological pressure and marginalized from the hetero-normative valued society.

Globally, LGBT movements are raised up their voices against anti-homosexual laws and human rights violations upon sexual minorities. All of the European countries have taken steps to de-criminalize homosexual behaviours and most of the domestic jurisdictions such as Finland, Denmark, and Sweden offer legal recognition for same-sex marriages and same-sex civil unions.

\section{Methodology}

This study mainly focused on to the sexual minor community. The research is qualitative research. In social science field, qualitative researches are more popular. These types of researches are designed to reveal a target audience's range of behaviour and the perception that drive it with reference to specific topics or issues.

This is also a literary research and mainly based on internet. Scholarly articles, newspaper articles and previous researches in relation to sexual minorities in Sri Lanka may be analyzed.

Articles from magazines and journals, scholarly books may be retrieved as a secondary source.

\section{Limitations}

Although this research is mainly focused on rights and positions of sexual minorities. It was not conducted direct interviews with sexual minorities due to practical difficulties and limited only to internet-based articles and scholarly works.

\section{Literature Review}

An overview of Constitution of Sri Lanka in relation to sexual minorities

The Constitution of the Democratic Socialist Republic of Sri Lanka identified and consolidated the fundamental rights of citizens. From Article 10 to 14 of the Constitution, the fundamental rights are prescribed and from article 15 to 17 the restrictions of fundamental rights and remedies for infringements of fundamental rights are contained. 
Article 12(2) of the constitution attempts to ensure the rights of non-discrimination among the citizens of Sri Lanka. According to the Article 12 (2) "no citizen shall be discriminated against the ground of race religion, caste, sex, language, political opinion, and place of birth or any one of such grounds." Through this provision, the sexual minor community is safeguarded from the discrimination due to their sexual orientation or sexual diversity. The Article 12(3) is given the opportunity to citizens to enter to any public place without considering their race, religion, caste, sex or any other of such grounds. Through this provision, the sexual minorities are permitted to access to public places without any discrimination.

Penal Code of Sri Lanka and sexual minorities

The Sri Lankan Criminal Justice system was directly influenced by British Victorian rules as Sri Lanka was a British colony till 1948. The Penal Code of Sri Lanka was formulated by British Parliament in 1883. The root codification of Penal Code of Sri Lanka stated that gayness as an offence. It was identified as "gross indecency among men". But the British Parliament or British Lawmakers were not acknowledged about the existence of lesbianism or sex between women . Therefore they have not categorized lesbianism as a criminal offence under Penal Code of Sri Lanka.

Through 1995 amendment the penal code ${ }^{1}$ the lesbianism also acknowledges as an offence in Sri Lanka. The word "men" was substituted with "persons" from the amendment, thereafter the lesbianism also considers as a sexual offence in Sri Lanka.

Further, section 365 of Penal Code ${ }^{2}$ is criminalized under the offence called "unnatural offences". According to Penal Code, unnatural offences are called "carnal intercourse against the order of nature with any man, women or animal".

Cheating by Personation ${ }^{3}$

This provision also used by Police to target sexual minor community especially, transgender people and cross-dressers.

Vagrancy Ordinance

This Ordinance came into the force in 1824 in relation to the law regarding vagrants. The provisions of this outdated ordinance pave the path to police to criminalize and discriminate the innocent sexual minorities especially, section 7 of the ordinance. It states that "soliciting and act of indecency in public places as an offence". The police have been used this provision to harass and deter the sexual minorities.

International Covenant on Civil and Political Rights (ICCPR)

ICCPR is a cardinal treaty to recognize and promote the human rights of human beings. Sri Lanka also a state party to the covenant and should promote and ensure the rights of citizens of Sri Lanka without any

\footnotetext{
${ }^{1}$ Section 365A-Any person who acts of gross indecency with another person shall be guilty of an offence, and shall be punished with imprisonment which may extend to two years or with fine or without fine or both.

${ }^{2}$ Section 365-Whoever has carnal intercourse against the order of nature with any man, woman or animal should be punished with imprisonment which may extend to ten years or with fine or with both.

${ }^{3}$ Section 399-Any person who pretends to be some other person or by knowingly substituting one person for another or representing him or such other person really is should be punished with imprisonment which may extend to one year or with fine or both.
} 
discrimination. Article 26 of the covenant states that "all persons are equal before the law and are entitled without any discrimination on the equal protection of the law". Further article 2 states that "states parties shall ensure the rights recognized in the covenant without any discrimination such as any ground of race, colour, sex religion, political or any other opinion, national or social origin property birth or other status". Therefore the government should ensure the rights prescribed in the covenant without considering the sexual orientation or sexual diversity of citizens of Sri Lanka.

International Covenant on Economic, Social and Cultural Rights (ICESCR)

The ICESCR also one of the prominent human rights covenants under international law. Sri Lanka also a signatory to the covenant, therefore Sri Lanka has a binding capacity over the covenant. According to the article 2 para, 2 of the covenant "the rights enunciated from the covenant should be practised among the citizens of state parties without discrimination grounds such as race, language, colour, sex, birth or other status." Therefore the sexual minorities have the opportunity to enjoy all the rights enunciated in the covenant without any discrimination. For example, article 9 of the covenant states that "everyone has right to social security including social insurance". The sexual minorities also including into the category of "everyone" therefore they also have right to social security in their societies without any discrimination.

In the context of Sri Lanka, there are plenty of scholarly articles written by academics and LGBT activists. Much of these articles were written by LGBT activists and non-governmental organizations work for sexual minorities. There is relatively little written by legal scholars regarding LGBT community in Sri Lanka.

In their work MAN Chandrathilake and P.Mahanamahewa" held that "Sri Lanka is in the backwater of the global gay rights village requires no further explaining". According to them the law cannot and should not penalize persons due to their sexual preferences.

\section{Discussion}

This particular section discusses two aspects regarding sexual minorities.

The rights consolidated under Constitution of Sri Lanka and international treaties ratified by Sri Lanka with regard to sexual minorities will be discussed in comprehensively.

The position of the sexual minorities in the context of Sri Lankan Criminal Justice System will be discussed in the second part of this section. The contemporary penal laws regarding sexual behaviours will be retrieved. Conflict among laws and sexual preferences of sexual minorities will be argued to provide an idea of the present situation in Sri Lankan society.

Constitution of Sri Lanka and Sexual minorities

As mentioned in the literature review the constitution of Sri Lanka prescribes the fundamental rights of the citizens. According to the article12 (1), (2) and (3), all citizens are equal before the law and sex should not be a ground of discrimination. Even though the Sri Lankan justice system does not use any specific mechanism to protect the sexual minorities from discrimination on the basis of sexual orientation. While studying the constitutional law and criminal law relating to sexual minorities in Sri Lanka prima facie conflict could be noticed in the fundamental rights and penal code. The penal code criminalizes the same-sex conduct, whereas constitution states that the sex should not be a ground of discrimination. These contradictory legal provisions

\footnotetext{
${ }^{4}$ Sexual Orientation and Human Rights; Applicable Laws of Sri Lanka and the UK, Proceedings of $8^{\text {th }}$ International Research Conference, KDU, November 2015
} 
create a conflict between penal laws and human rights arena whereupon sexual minorities are aggrieved in an unreasonable manner.

Sri Lanka does not recognize the right to life ${ }^{5}$, right to privacy and right to health as fundamental rights. Further, Sri Lankan society gives more priority to good morals other than the privacy of individuals. Through the article 15 (7) of the constitution of Sri Lanka, some fundamental rights could be restricted to protect the public morality. ${ }^{6}$ This provision could be used to marginalize and narrow down the rights of sexual minorities. Further, so-called public morality could be used to discriminate the sexual minorities. On the other hand, the religious and devotional activists and traditionalists treat sexual minorities as perverters and wrongdoers.

Overview of International Covenant on Civil and Political Rights (ICCPR) and sexual minorities

As a signatory to the ICCPR, Sri Lanka has an obligation to ensure the civil and political rights of the citizens in the territory. Article 26 of the ICCPR ensures the right of equity before the law ${ }^{7}$. Further Article 2 of the covenant clearly defines that, "all state parties should safeguard the rights of citizens without any discrimination such as sex". Therefore as a state party to the covenant, Sri Lankan government should ensure the rights of sexual minorities without any discrimination.

International Covenant on Economic, Social and Cultural Rights (ICESCR)

The International Covenant on Economic, Social and Cultural Rights also a cardinal Human Rights treaty and Sri Lanka as a state party to the covenant it should be protected, promoted and respected the economic, cultural and social rights acknowledged by the covenant. The section 2 of article 2 of the covenant states that "the rights enunciated in the covenant should not be discriminated such as any grounds of sex". Further, the covenant safeguards the work right of every person under article 6 . The work rights, equal opportunity and the discrimination-free environment in workplaces due to sexual orientation could be enjoyed by the LGBT community in the light of this article.

Most of the times the sexual communities especially, gays and lesbians are forced to attend heterosexual marriages by their families in Sri Lanka ${ }^{8}$.This situation creates various types of disputes among sexual minorities, their families and spouses. The Article $10^{9}$ identifies "entering into the marriage with free consent

5 The Supreme court has accepted the Right to Life as a fundamental right- Bulankulame V Secretary, Ministry of Industrial Development and Others(Eppawala Case) 3 SLR,243

${ }^{6}$ The exercise and operation of all the fundamental rights declared and recognized by Article 12, 13(1), 13(2) and 14 shall be subject to such restrictions as may be prescribed by law in the interest of national security, public order and the protection of public health and morality.

${ }^{7}$ Article 26-All the persons are equal before the law and entitled without any discrimination to the equal protection of Law. In this respect, the law shall prohibit any discrimination and guarantee all persons equal and effective protection against discrimination on any ground such as race, colour, sex, language, religion, political or other opinions, national and social origin, property, birth or other status.

${ }^{8}$ Violations by Sri Lanka of Economic, Social and Cultural Rights of Lesbian, Gay, Bisexual, Transgender, Intersex and Questioning People, Submitted for consideration at $61^{\text {st }}$ session of the committee of Economic, Social and Cultural Rights, submitted by Equal Ground Sri Lanka,(May 2017),p 7,available at https://www.INT_CESCR_CSS_LKA_27401_E.pdf (last visited 10 $0^{\text {th }}$ April 2018)

${ }^{9}$ Article 10(1)-Marriage must be entered into with the free consent of the intending spouses. 
as a right of individuals". Through this provision forced marriages are debilitated. This provision does not specifically mention about sexual minorities even though they could use it as a shield against forced marriages.

Majority of Sri Lankans treated, sexual minorities as perverters or sinners. If a sexual minority is a member of a family, the society is ignored the whole family. Therefore most of the family members are reluctant to divulge about their sexual minority member and most of the time such members are set apart from families and they are maltreated ${ }^{10}$. The ICESCR identifies the adequate living conditions of everyone as a fundamental right. ${ }^{11}$ Sri Lanka as a signatory to the covenant it has an obligation to ensure the minimum standard of living conditions of citizens. Therefore both government and general public should facilitate the standard living conditions for sexual minorities without any discrimination.

The Article 12 of the Covenant prescribes that "the enjoyment of mental and physical health as a human right" $"$. In Sri Lanka, the primary health care is totally free for every citizen. A well developed and wellequipped government hospital system and well-trained health care providers are available in Sri Lanka. As citizens of Sri Lanka sexual minorities have the right to access free medical facilities. Unfortunately, these people are discriminated and stigmatized in the public healthcare sector ${ }^{13}$.LGBT community is labelled as mentally ill population and health staff is often unaware and insensitive about their health issues and other health-related matters. ${ }^{14}$

Penal Laws regarding sexual minorities in Sri Lanka

The act of gross indecency and unnatural offences are punishable offences under penal code of Sri Lanka. According to the penal code, "unnatural offences are the offences of carnal intercourse against the order of nature with any man, woman or animal". The word "unnatural" means different from what is normally expected or different from anything in nature" 15 . The word "carnal" denotes "connected with the body or sex"16. While considering these meanings, the unnatural offences means "sexual activates contrary to nature". These activities could be identified ${ }^{17}$ as sodomy $^{18}$, buggary ${ }^{19}$, bestiality ${ }^{20}$, tribadism ${ }^{21}$, sadism $^{22}$,

${ }^{10}$ Human Right Watch, All five fingers are not same, Discrimination on Grounds of Gender Identity and Sexual Orientation in Sri Lanka,(2016) p 48, available at https://www.hrw.org/sites/default/files/report_pdf/srilanka0816web.pdf (last visited 5April 2018)[herein after Human Right Watch Report 2016].

11 Article 11(1)-Right of everyone as an adequate standard of living for himself and his family including adequate food, clothing and housing and continues improvement of living condition.

12 Article 12(1) - The States Parties to the present Covenant recognize the right of everyone to the enjoyment of the highest attainable standard of physical and mental health.

${ }^{13}$ Human Right Watch Report 2016, p 1,3,39

${ }^{14}$ Ibid, p 39

${ }^{15}$ Oxford Advanced Learner's Dictionary, $6^{\text {th }}$ Edition

16 .ibid

${ }^{17}$ Brother John Antony, Petitioner V The State, Respondent,1992, CrLJ 1352

${ }^{18}$ Non-coital carnal intercourse with the same sex or opposite sex partner e.g.-per anus or mouth 
masochism ${ }^{23}$.With regard to section 365 of the Penal Code of Sri Lanka sodomy, buggery, tribadism and bestiality are categorized under unnatural offences in Sri Lanka.

The section 365 A of Penal Code does not describe what an "act of gross indecency" actually is. No any clear definition or interpretation of what counted as gross indecency. Gross indecency is much easier to prove than unnatural offences. Under unnatural offences, it is mandatory to prove the existence of penetration. But under section $365 \mathrm{~A}$, the law is silent and does not give any explanation to constitute the offence. Therefore the practice of gross indecency cannot be clearly demarcated. For example, two men are kissing and cuddling in a public place or a private place could not constitute the offence of unnatural offence even though it could constitute the offence of gross indecency.

From the recent judgement Supreme Court of Sri Lanka ${ }^{24}$, oral sex practice among two men in a vehicle is considered as an offence under the section $356 \mathrm{~A}$ of Penal Code. In his judgement, Aluwihare J. held that "the contemporary thinking, that consensual sex between adults should not be policed by the state nor should it be grounds for criminalisation. However, the offence remains very much a part of our law". But none of the court decisions defines or interpret what an "act of gross indecency" actually is. According to the Joint Submission for 3rd cycle UPR review of Sri Lanka report "gross indecency is not defined by the law or any Sri Lankan court decision, the current law is understood to target sexual acts and displays of romantic affection between two individuals of the same sex. Because the term "gross indecency" is left open to interpretation by police officers, prosecutors, and judges, the breadth and ambiguity of what could constitute "gross indecency" invites abuse". ${ }^{25}$

Through the section $399^{26}$ of Penal Code the offence "cheating by personation" makes LGBT community as offenders. Most of the times transgender community are targeted by the police, based on their gender identity. Because their gender identity differs from the sex assign at the birth. National identity card and passport are issued based on the birth certificate, therefore transgender's present gender identity does not match with their documents. Further, their appearance does not match with the gender identity included in their documents. As a result of this entanglement, the transgender community is happened to unnecessary questioning by the police and everyday life events. Many incidents have reported that the transgender people were arrested by police under section 399 of Penal Code.

${ }^{19}$ sexual intercourse per anus by a man with another man or woman, or intercourse per anus or vagina by a man or woman with an animal

${ }^{20}$ sexual intercourse by a human with a lower animal

${ }^{21}$ Friction of the external sexual organs by a woman with another by mutual bodily contact to have sexual desire

${ }^{22}$ Sexual excitement in response to inflicting pain upon other people

${ }^{23}$ practice of getting sexual pleasure from being physically hurt from others

${ }^{24}$ SC Appeal No 32/11, Galabada Payagalage Sanath Wimalasiri, Petitioner V AG, Respondent

${ }^{25}$ Joint Submission for $3^{\text {rd }}$ cycle UPR review of Sri Lanka, Coalition of NGO's for UPR-Sri Lanka (SOGI), Human Rights violations against LGBTIQ individuals in Sri Lanka

${ }^{26}$ See Supra note 3 
The Vagrancy Ordinance ${ }^{27}$ is another outdated act, which often criminalizes sexual minorities. The act of gross indecency is identified as an offence under the section 7 of this ordinance also ${ }^{28}$, although the act of "gross indecency" is not defined in the ordinance. Further, section 7 states that "soliciting in or about any public place for the purpose of committing illicit sexual intercourse or indecency as an offence". But the act of "illicit sexual intercourse" does not interpret in the ordinance. Many incidents have reported that the police use these legal provisions to target and harass the transgender people ${ }^{29}$. Similarly, they are arrested by the police under the section 399 of the Penal Code and the Vagrants Ordinance. ${ }^{30}$

The Prevention of Domestic Violence Act ${ }^{31}$ gives the appropriate legal protection to victims of domestic violence. Through this act, the ex-spouses and cohabiting partners are categorised under aggrieved parties and they could seek the protection from domestic violence offences. Unfortunately, the same-sex partners do not categorise as one of the aggrieved parties, therefore, they cannot seek the protection from this act.

\section{Legal Gender Recognition in Sri Lanka}

Sri Lankan Justice System does not provide a clear path to changing legal gender. Before the year 2016 transgender community was unable to amend their official documents such as national identity cards, birth certificates, after their gender reassignment. Due to this lacuna, transgender community faced obstacles while accessing employment, housing, higher education and healthcare. In the year 2016, a circular was passed by Ministry of Health to issue Gender Recognition Certificate for the transgender community. Through this certificate, the individuals would get a chance to change their gender indicated in official documents such as birth certificates, national identity cards, and passports. Issuing the gender recognition certificate still is in the state of administrative policy under a circular and does not consider as a law. Therefore this policy is under the control of administrative officials and their discretion is directly influenced by this process.

However obtaining a Gender Recognition Certificate also a challenge to the transgender community. Under this certification process, three steps of difficult proceedings should be fulfilled by the individuals. (a)The individual should be assessed by a psychiatrist, (b) the psychiatrist should be certified that "the person was referred for hormonal therapy and necessary surgical treatments", (c) the psychiatrist should certify that "the person underwent the gender transformation process". ${ }^{32}$ According to this circular, to obtain a Gender Recognition Certificate, the transgender person should undergo a psychiatrist's assessment. Besides, appropriate hormonal therapy and surgical treatments such as gender confirmation surgery should undergo to obtain the certificate. In Sri Lankan context these types of surgeries are rare and cost-effective. Therefore a limited people could get a chance to undergo the sex reassignment surgeries. Majority of the transgender

\section{${ }^{27}$ Ordinance No 4 of 1841}

${ }^{28}$ Section 7 (b) of Vagrants Ordinance-Any person found committing any act of gross indecency or found behaving with gross indecency in or about any public place shall be guilt an offence and shall be imprisonment or fine or both.

${ }^{29}$ Human Right Watch Report 2016,p 11,16,30,37

${ }^{30}$ Ibid

${ }^{31}$ Act No 34 of 2005

32 Dr. P.G Maheepala, Director General of Health, Issuing of Gender Recognition Certificate for Transgender Community, General Circular Number-01-34/2016,16 June 2016 
community unable to obtain the certificate, therefore, their official documents cannot be amended with their present gender identity.

In Sri Lanka, official documents such as national identity card and birth certificate have a significant value to identify the appropriate person. In the government institutions such as banks, government offices, educational institutions, police, the trans genders should tender their official documents for the identification process. In every such situation, these people are faced with discrimination, harassments and violations due to contrariety of actual gender identity and the documentary gender recognition.

Heteronormative value oriented Sri Lankan society and Transgender community

In Sri Lankan society the gender identity is classified only into two categories, i.e male and female. The traditional Sri Lankan society vehemently ignores the concept of the third gender. Due to this discrimination and stigmatize situation LGBT community is faced various problem in housing and employment. Finally, these people are working as sex workers as they do not have any alternative path to survive within this society.

LGBT people are facing more vulnerable when their appearance is not tally with the social expectation. The society called the transgender people with a disgusting word "Nachchi or Ponnaya".But in ritual and cultural occasions, Trans gender's performances such as dances acquired a great value and attraction from the audience. Even though they are stigmatized by the heteronormative value oriented Sri Lankan society in a ruthless manner.

\section{Conclusion and Recommendation}

Sri Lanka is in the nethermost position of LGBT rights in world ranking requires no further explanation. In South Asian region countries such as India, Nepal and Bangladesh shows more amenable and attentive in LGBT rights while compared with Sri Lanka. Globally the LGBT rights are acquired with remarkable achievements in the last few decades. In the year 2017, the debate of homosexuality came to the parliament of Sri Lanka. In $17^{\text {th }}$ January 2017, the Sri Lanka cabinet met to discuss the proposal of decriminalizing the homosexuality in Sri Lanka ${ }^{33}$.Unfortunately, the decision was rejected by the majority of cabinet members stating that "when homosexuality is legalized it may cause various social problems" and the Buddhist clergy community was vehemently opposed the decision. ${ }^{34}$ The sexuality differs from individual to individual and it is the privacy of person's. Specific religious groups or any other social groups cannot derogate the sexual behaviours or sexual preferences of others. The law cannot divide the sexual behaviours of persons as legal and illegal and lawmakers should not peep through the windows of the bedroom of persons to criminalize the sexual conduct of them.

At present, a wide dialogue is created on the new constitutional reform in Sri Lanka. The new government elected in 2015, gave a new hope to Sri Lanka about a new constitution which addresses current requirements of the citizens. This stage creates a space to discuss the dilemmas of the current constitution of Sri Lanka. Through the committee of Constitutional Reforms, new recommendations were proposed to eliminate the discrimination of LGBT community. Through the paragraph 28 of the report ${ }^{35}$ under subtopic "Right of People

https://www.pinknews.co.uk/2017/01/18/sri-lanka-just-took-a-decision-on-whether-to-legalisehomosexuality/

$34 \quad$ https://www.sbs.com.au/topic/sexuality/agenda//article/2017/01/19/srilanka-rejects-move-legalisehomosexuality-0[last visited 2nd May 2018]

${ }^{35}$ https://www.yourconstitution.lk/FPRCRpt/FPRC_english_report-A4\&gs_[last visited $4^{\text {th }}$ May 2018] 
with Diverse sexual and Gender Identities," it discusses widely on constitutional rights and protection of LGBT community. Further, it recommends that the "section 365 and 365(A) of Penal Code should be repealed and amended to ensure full compliance with article 2 and 26 of ICCPR" 36 . Therefore Sri Lanka should take immediate actions to follow these recommendations while consolidation of the new constitution.

Whenever there are any amendments to the acts of Sri Lanka it should be pass from the parliament with the majority. The parliament of Sri Lanka often consolidates new laws and amends acts contemporary with the present world. Unfortunately, the parliament wilfully evades the discussion of LGBT issues. .But the parliament should open platform to negotiate with civil organizations and other LGBT activists to create a dialogue of LGBT rights and their position. The government should more attentive and mindful of contemporary modern dimensions of sexual minorities in the global village and try to adopt appropriate issues to the legal system of Sri Lanka.

Under the homosexual offences, only a few cases have filed in criminal courts and a lesser amount of numbers reached to the upper courts. The sexual minorities harass by the Police due to the anti-homosexual laws. Especially transgenders and cross-dressers are targeted and, sexually abused or raped by the police. These victims are reluctant to lodge complaints against the police offers due to the fear of revenge, therefore they are often targeted and assault by the police officers. At present, an official dialogue about the way of treating LGBT community is emerging and as a result of that, a considerable safeness is creating in the society for them. Further, civil organizations and LGBT activists contribute their strength to build up a safe surrounding for the sexual minorities. The Government should advise the police department to take appropriate actions to respect the rights of sexual minorities and protect their dignity.

In Sri Lanka, a considerable percentage of sexual minorities work as sex workers. High prevalence of HIV/AIDS could be noticed among them especially, among gay men. Therefore they should be screening and testing for HIV to prevent it. In the healthcare sector, these people are discriminated and ill-treated by the health care workers. This situation creates a barrier to them to access the health care to getting tested for HIV and STDs (sexually transmitted diseases). Therefore, the discrimination should be eradicated from healthcare sector to protect sexual minorities from HIV. Further, health care officials should engage in effective programmes collaborate with sexual minorities to prevent HIV.

As one of the commonwealth countries, the Sri Lanka should subscribe and respect to the Commonwealth's values and principles outlined in the Commonwealth Charter. The chapter XII of the charter recognises the gender equality as essential components of human development and basic human rights. Therefore Sri Lanka also binds by these principles and should take immediate actions to safeguard the sexual minorities.

The Yogyakarta Principles are a set of principles of application of international human rights law in relation to sexual orientation and gender identity. This document addresses 29 principles those are important to LGBTIQ people. In the year 2017, another set of additional principles were amalgamated to the Yogyakarta principles and they are called "Yogyakarta Principles plus 10".The policymakers, LGBT activists from national and international forums have treated the Yogyakarta principles as the cardinal authoritative document of sexual minorities despite that these principles are not legally binding for any sovereign state or governing body. Nevertheless, Sri Lankan policy makers and legal drafters may have an opportunity to take cue from these principles while preparing new laws and regulations for sexual minorities.

Furthermore, it should be understated that laws alone cannot seek remedy for embedded ideologies prevailing in the society regarding sexual minorities. Therefore awareness programmes should be conducted by police officers, health sector, and other governmental and non-governmental organizations. The information sending

36 ibid 
through the clergy society may give fruitful result and definitely, it may evince more achievements. Ultimately, these recommendations would resulted in the protection of rights of sexual minorities and ameliorate their position in Sri Lankan society while creating a safe and prestigious surrounding for them.

\section{References}

Brother John Antony, Petitioner V the State, Respondent, 1992, CrLJ 1352

Bulankulame V Secretary, Ministry of Industrial Development and Others (Eppawala Case) 3 SLR, 243

Butterworth, B, 2017 Sri Lanka just took a decision on whether to legalise homosexuality https://www.pinknews.co.uk/2017/01/18/sri-lanka-just-took-a-decision-on-whether-to-legalisehomosexuality/ 18th January 2017, 10:09 AM [Accessed 18th April 2018]

Chandrathilake, MAN., Mahanamahewa, P,2015, Sexual Orientation and Human Rights: Applicable Laws of Sri Lanka and the UK, Proceedings of 8th International Research Conference, KDU, Published November 2015 [pdf], https://scholar.google.com/citations?user=MVB8-0QAAAAJ\&hl=e[Accessed 4th April 2018]

Equal Ground of Sri Lanka, 2017,Violations by Sri Lanka of Economic, Social and Cultural Rights of Lesbian, Gay, Bisexual, Transgender, Intersex and Questioning People, Submitted for consideration at the 61st session of the committee of Economic, Social and Cultural Rights, [pdf] https://www.INT_CESCR_CSS_LKA_27401_E.pdf [Accessed 10th April 2018]

Human Right Watch, All five fingers are not same, Discrimination on Grounds of Gender Identity and Sexual Orientation in Sri Lanka, 2016 [pdf] https://www.hrw.org/sites/default/files/report_pdf/srilanka0816web.pdf [Accessed 5 April 2018].

Human Rights Commission of Sri Lanka Proposals for Constitutional Reform - 2016 [pdf] hrcsl.lk/english/.../2016/.../Proposals-for-Constitutional-Reform-by-HRC-in-English...[Accessed 4 th May 2018]

International Covenant on Civil and Political Rights

International Covenant on Economic, Social and Cultural Rights

Joint Submission for 3rd cycle UPR review of Sri Lanka, Coalition of NGO's for UPR-Sri Lanka (SOGI), Human Rights violations against LGBTIQ individuals in Sri Lanka [pdf] https://www.ilga.org/downloads/stakeholders_report_SriLanka_UPR28.pdf [Accessed 7th April 2018]

Morgan, M., 2017 Sri Lanka rejects move to legalise homosexuality 17th January 2017 https://www.sbs.com.au/topics/sexuality/agenda/article/2017/01/19/sri-lanka-rejects-move-legalisehomosexuality-0 [Accessed 2nd May 2018]

Penal Code of Sri Lanka

Prevention of Domestic Violence Act, No 34 of 2005

SC Appeal No 32/11, Galabada Payagalage Sanath Wimalasiri, Petitioner V AG, Respondent

The Constitution of the Socialist Republic of Sri Lanka

Vagrancy Ordinance No 4 of 1841 